\title{
Situationspraktik - mellem universitet og praksis
}

Bo Skøtt, adjunkt, Institut for Design og Kommunikation, Syddansk Universitet i Kolding. Rie Troelsen, leder, Center for Universitetspaedagogik, Syddansk Universitet.

\section{Faglig artikel (bedømt af redaktionen)}

Denne artikel omhandler et forsøg med integration af praksis i undervisningen, som har til formål, 1) at give de studerende en fornemmelse for, hvordan fagene på uddannelsen har relevans for arbejdet i praksis, og 2) at kvalificere de studerende til mødet med praksis. Derfor inddrages iscer Etienne Wenger og Jean Laves teorier om 'praksisfaellesskaber' med fokus på 'situeret laering' i overvejelserne over og planlaegning af forsøget. Forsøget betegnes Situationspraktik og organiseres ud fra tre overordnede aktiviteter: asynkrone studieaktiviteter (litteraturstudier, planlaegning og forberedelse af delarrangementer), klassisk konfrontationsundervisning (teori- analyse og metodepraesentation) og som et arrangement, hvor resultaterne af disse aktiviteter omsaettes i praksis. I forsøget deltager 12 studerende, der alle går på 4. semester.

Situationspraktikken resulterer for underviser i erfaringer med, hvilke poedagogiske muligheder og udfordringer der er med at facilitere loeringsfollesskaber de studerende imellem og med inddragelse af eksterne stakeholders.

\section{Indledning}

Hvad kan jeg egentlig bruge min uddannelse til? Hvordan hænger dét, jeg lærer på universitetet, sammen med dét, der foregår i virkeligheden? Og hvorfor er denne teori vigtig i forhold til min fremtidige praksis? Dette er spørgsmål, som mange studerende stiller sig selv i løbet af deres uddannelse. Der er mange gode grunde til, at uddannelserne fra første færd bestræber sig på at besvare disse spørgsmål. For eksempel kan afstemning af forventninger mellem uddannelse og studerende føre til mindre frafald (Ulriksen, Madsen \& Holmegaard, 2014). Men det kan også tydeligg $\varnothing-$ re motivationen for og relevansen af fagene i uddannelsen og sikre, at de studerende ikke oplever et praksischok efter endt uddannelse (Lindhart, 2007) eller helt generelt fremme de studerendes employability (Knight \& Yorke, 2004).

Nærværende artikel tager udgangspunkt i udviklingen af et undervisningselement, som vi kalder 'situationspraktik'. Situationspraktikken kan betragtes som en metode, der er udformet som en mellemting mellem korte besøgspraktikker og længerevarende, mere ordinære praktikforløb. Den har som formål, sammen med de studerende, at etablere et forsøg med en alternativ form for praktik, der giver de studerende svar på spørgsmål om forskellige fagelementers relevans for deres fremtidige 
praksis og dermed en bedre forståelse for, hvad det fremtidige arbejde kan bestå i. Vores antagelse er, at de studerendes mulighed for at indgå i faglige praksisfællesskaber med professionelle udøvere af faget og borgere tidligt i studiet kan medvirke til at gøre deres læring mindre situeret og både modvirke frafald og praksischok efter endt uddannelse. Situationspraktikken er den pædagogiske ramme, hvori dette afprøves.

\section{Læring som social praksis}

Når vi i nærværende forsøg skaber tætte relationer mellem praksis og undervisning, sker det, fordi vi har en antagelse om, at der i praksis finder processer sted, der er væsentlige for de studerendes forståelse af fagenes relevans og for deres fremtidige opgaveløsning. Disse processer kan ikke erfares gennem undervisningens teoretiske, metodiske eller analytiske introduktioner eller gennem simuleringer. Derfor inddrager vi teorier om 'praksisfællesskaber' med fokus på 'situeret læring' i overvejelserne over og planlægning af arrangementet.

Etienne Wenger (1998) definerer praksisfællesskaber som fællesskaber, hvor mennesker er aktive sammen og indgår i en række aktiviteter, der dels er rettet mod forskellige former for praktisk opgaveløsning, dels mod at skabe de sociokulturelle relationer og rammer som løsningen af disse opgaver medfører. Den praksis, som fællesskaber bygger op for at løse deres problemer, indeholder med andre ord normer for hvilke handlinger, rutiner og strukturer, der er adækvate for det pågældende fællesskab. I Wengers definition af praksisfællesskaber ligger endvidere et opgør med en mere funktionalistisk opfattelse af, at læring kun finder sted, når læring er målet. I et livshistorisk perspektiv indgår vi alle i et utal af praksisfællesskaber og gerne samtidigt i flere forskellige. Her bliver læring en sekundær, men behagelig, effekt af at deltage i sociale eller kulturelle aktiviteter. Læring betragtes da som en konsekvens af, at mennesker færdes og interagerer sammen, hvorfor læring som oftest finder sted sideløbende og kontinuerligt, gerne i form af u- eller semiformelle erfaringsprocesser (Wenger, 1998).

'Situeret læring' henviser til læring som situeret i specifikke sociale situationer og understreger den relationelle forbundethed, der eksisterer mellem aktiviteter i praksis og den erfaringsdannelse, der finder sted hos det enkelte menneske (Lave \& Wenger, 2003). Denne forbundethed udgør lejlighedsvist en problematisk størrelse, fordi kompetencer, viden og færdigheder ofte erfares som kontekstafhængige: i mange professionelle praksisfællesskaber bliver den studerende socialiseret ind i en bestemt sociokulturel diskurs, hvori opgaveløsning og aktivitet foregår. Når forudsætningerne for opgavernes løsning ændrer karakter - for eksempel i overgang mellem studie og erhvervsarbejde - har visse studerende vanskeligt ved at omsætte kompetencer, viden og færdigheder til praksis (Rasmussen, 1999). 
Principielt giver opmærksomheden på 'praksisfællesskaber' og 'situeret læring' to mulige fokusser i vores forløb: 1) et der sigter mod at opbygge et praksisfællesskab med deltagelse af studerende og borgere fra praksis, for gennem learning by doing at gøre sig erfaringer i praksis, og 2) et, der sigter mod at opbygge et praksisfællesskab med deltagelse af studerende og professionelle udøvere af faget for gennem en form for sidemandsoplæring at få indblik i den professionelles praksis. Da den overordnede ambition med situationspraktikken er at kvalificere de studerende til mødet med borgerne, er det især den første form, der er i fokus. Men under udførelsen af forsøget viser sig et tredje muligt fokus: 3) et, der sigter mod at opbygge et praksisfællesskab med deltagelse af de studerende, der går på holdet!

\section{Situationspraktik som undervisningsform}

\section{Beskrivelse af uddannelse, fag og studerende}

Situationspraktikken bliver i denne artikel eksemplificeret i kurset Målgruppestudier og videns- og smagskultur, foråret 2015 ved Bibliotekaruddannelsen på SDU. Der er tale om et 5 ECTS-fag, i Studieordningen (Det Humanistiske Fakultet SDU, 2015) beskrevet som 3 ugekurser og projektarbejde svarende til 2 timers ugentlig undervisning fra 1. februar til 15. maj. Af 12 studerende på det aktuelle hold tilhører 10 studerende stamholdet, for hvem kurset er obligatorisk, mens to studerende kommer fra forskellige designstudier og tager kurset som valgfag. Som altid på uddannelsen til bibliotekar er der en klar overvægt af kvinder i alderen 20 - 35 år med anden erhvervsfaglig uddannelse og/eller -karriere bag sig. På nærværende hold er 4 studerende uddannede lærere eller pædagoger, mens 3 har haft karrierer i private virksomheder. Andre 3 har påbegyndt eller gennemført andre uddannelser, før de valgte bibliotekaruddannelsen. Kun 2 studerende kommer direkte fra gymnasiet.

I samarbejde med disse studerende udvikles en lektionsplan (figur 1), så der i udgangspunktet reserveres 13 lektioner á ca. to timers varighed fordelt over et tilsvarende antal uger i foråret 2015 til konfrontationsundervisning og praktik. Derudover aftales det, at de studerende udfører en række aktiviteter asynkront med undervisningen. I 'konfrontationsundervisning' indgår oplæg, diskussion på/med holdet, summemøder og teoretiske, metodiske og analytiske introduktioner - og i 'praktik' indgår både et indledende besøg, statusmøde, samt ultimativt gennemførelse af arrangementet "SDU studerende invaderer biblioteket" (3 timer ultimo april) på Kolding Bibliotek. Under betegnelsen 'asynkrone studieaktiviteter' hører litteraturstudier, valg af tematik og målgruppe, samt hele planlægningen og organiseringen af de studerendes respektive delarrangementer ( $\mathrm{fx}$ bytte-bog-bod, børnebøger på skærmen og lav dit eget bogmærke). Disse aktiviteter afrapporteres som oplæg i plenum, hvor det er muligt at diskutere baggrund, indhold og udførelse. Monitoreringen af disse aktiviteter udgør, sammen med de studerendes skriftlige og mundtlige evalueringer, artiklens empiriske grundlag. 


\begin{tabular}{|c|c|c|c|}
\hline \multicolumn{4}{|c|}{ Figur 1: Undervisningsplan for 'Målgruppestudier og videns- og smagskultur', forår 2015.} \\
\hline & $\begin{array}{l}\text { Asynkrone studieaktivi- } \\
\text { teter (studerende) }\end{array}$ & $\begin{array}{l}\text { Konfrontationsundervisning } \\
\text { (studerende og underviser) }\end{array}$ & $\begin{array}{l}\text { Praksis (studerende, } \\
\text { underviser og kontakt- } \\
\text { person) }\end{array}$ \\
\hline Februar & $\begin{array}{l}\text { Påbegynde litteratur- } \\
\text { studier } \\
\text { Brainstorme og overveje } \\
\text { mulig(e) udformning(er) } \\
\text { af og indhold i del- } \\
\text { arrangementer }\end{array}$ & $\begin{array}{l}\text { Kursets indhold og opbyg- } \\
\text { ning } \\
\text { Situationspraktikken og } \\
\text { dens mulige indhold } \\
\text { Introduktion til teorier og } \\
\text { metoder }\end{array}$ & $\begin{array}{l}\text { 25. februar - første fæl- } \\
\text { lesmøde med kontakt- } \\
\text { person på Kolding Bib- } \\
\text { liotek. } \\
\text { - Skitsering af mulig- } \\
\text { heder og begræns- } \\
\text { ninger } \\
\text { Diskussion af form, } \\
\text { indhold, fysisk pla- } \\
\text { cering og tidspunk- } \\
\text { ter }\end{array}$ \\
\hline Marts & $\begin{array}{l}\text { Fortsatte litteraturstudi- } \\
\text { er } \\
\text { Konkretisere og frem- } \\
\text { lægge ideer } \\
\text { Valg af kommunikations- } \\
\text { og formidlingsmodeller }\end{array}$ & $\begin{array}{l}\text { Teorier, metoder og analy- } \\
\text { ser af praksis } \\
\text { Målgruppestudier - } \\
\text { definitioner og begreber } \\
\text { Cases og forskellige former } \\
\text { for 'best practises' }\end{array}$ & \\
\hline April & $\begin{array}{l}\text { Planlægning } \\
\text { Finjustering af delarran- } \\
\text { gementer } \\
\text { Fremskaffelse af for- } \\
\text { nødne former for hard- } \\
\text { ware, mv. }\end{array}$ & $\begin{array}{l}\text { Teoretiske og metodiske } \\
\text { aktiviteter fortsat i mere } \\
\text { konkretiseret form }\end{array}$ & $\begin{array}{l}\text { 8. april - statusmøde } \\
\text { med kontaktperson } \\
\text { - } \quad \text { Præsentation af } \\
\text { ideer } \\
\text { - Sparring, ideud- } \\
\text { veksling og diskus- } \\
\text { sion } \\
\text { Beslutning om fy- } \\
\text { sisk placering, in- } \\
\text { ventar mv. } \\
\text { Aftaler om presse- } \\
\text { meddelelse, PR- } \\
\text { materiale, plakater, } \\
\text { flyers }\end{array}$ \\
\hline
\end{tabular}

29. april mellem 16.00 - 19.00 gennemføres "SDU studerende invaderer biblioteket!"

Maj Slutevaluering 


\section{Beskrivelse af praktikforløb}

I bestræbelserne på at skabe læringsfællesskaber er én af de første opgaver som underviser at tage initiativ til at etablere en række aktiviteter og situationer, der dels skaber fælles rum for refleksion og erkendelse hos de studerende, dels simulerer den virkelighed, de studerende vil møde efter endt uddannelse. Disse aktiviteter består blandt andet $\mathrm{i}$ at:

1. udbygge det læringsfællesskab, de studerende allerede kender i kraft af at være studerende, til at omfatte andre aktører - samarbejdsparter - der potentielt kan stimulere til nye perspektiver, nye refleksioner og nye input.

2. skabe rum for og plads til refleksion over og rekontekstualisering af den faglige ("studie-situerede") viden, de studerende har efter ca. 11/2 år på studiet.

Ad 1. Udbygning af læringsfællesskab begynder allerede ved dag ét med introduktionen af situationspraktikken som et pædagogisk værktøj på kurset og af Kolding Bibliotek som samarbejdspartner. I forhold til Kolding Bibliotek er der etableret en kontakt på forhånd. Det skyldes en tolkning af facilitatorrollen som havende en understøttende og rammesættende funktion, der reducerer praksisfeltets kompleksitet, og som derfor tilstår de studerende mulighed for at gøre sig egne erfaringer med et fokuseret udsnit af dette praksisfelt.

Ad 2. Både optakten til og afholdelsen af situationspraktikken bliver et rum for refleksion over den erfaring, de studerende har gjort sig hidtil. Allerede i de indledende lektioner opstår spørgsmålet om det tilladelige $i$ at anvende og implementere ideer, viden og færdigheder, der bygger på tidligere erfaringer, private såvel som faglige, fra lektioner, andre kurser eller andre uddannelser. At inddrage tidligere erfaringer betragter underviser som hele forudsætningen for, at et forløb og et forsøg som "SDU studerende invaderer biblioteket!" kan etableres. At de studerende er i stand til at trække på tidligere erfaringer og egne fonde af viden bliver derfor et naturligt led $i$ at mindske læringens potentielt situationelle karakter. I gennemførelsesfasen reflekterer de studerende videre over deres formidlingsevner, og flere tilpasser dem faktisk til den aktuelle kontekst.

\section{Erfaringer fra situationspraktikken}

Det lykkedes ikke at formulere et praksisfællesskab mellem studerende og de professionelle på Kolding Bibliotek. Dertil var de studerendes tilknytning til biblioteket for kortvarig og sporadisk. De ansatte var orienterede om forløbet og bidrog velvilligt med indretning, opkobling, markedsføring med videre, men noget egentligt praksisfællesskab blev der aldrig tale om - måske fordi det aldrig var intentionen fra Kol- 
ding Biblioteks side. "SDU studerende invaderer biblioteket!" var det slogan, kontaktpersonen foreslog for forløbet - hvilket underbygger denne antagelse.

Når forsøget alligevel lykkedes i det omfang, det gjorde, skyldes det ikke mindst, at de studerende tog fagligt ejerskab over arrangementet som helhed og over delarrangementerne i særdelshed. Langt de fleste studerende arbejdede seriøst og engageret med at skabe interessante delarrangementer og viste sig villige til at transformere deres erfaringer fra undervisning og karrierer i deres interaktion med borgerne. Selvfølgelig var der udfordringer i nogle af delarrangementernes design: bogbytte-boden kom aldrig rigtig i gang, fordi det krævede, at borgerne havde bøger med, der kunne byttes. Foyeren gav god synlighed, men den medførte også, at de studerende stod meget tæt sammen, og nogle af de mere kreative delarrangementer tog mere plads end beregnet. Men på grund af sammensætningen af de studerende og deres karakteristika (forholdsvis mange modne og engagerede studerende) lykkedes det at få sat en del af deres tidligere erfaringer i spil i forhold til borgerne. Og når noget ikke gik som forventet, for eksempel i forhold til, hvor udfarende de som arrangører skulle agere under afviklingen af arrangementet, havde de en række menneskelige kvaliteter, der gjorde dem i stand til at improvisere.

Netop dette improvisationstalent, som nogle studerende havde, viste sig som en udfordring for praksisfællesskabet på holdet. På stamholdet eksisterede der allerede et socialt hierarki, som alle studerende forholdt sig til. Dette hierarki, der blandt andet byggede på engagement/dygtighed, faglige ambitioner og investering af tid og ressourcer i planlægningen af delarrangementerne, skabte nogle skæve grupper (fra én til fire deltagere), men kom tydeligst til udtryk gennem gnidninger under afviklingen af "SDU studerende invaderer biblioteket!" Under evalueringen tematiseredes dette som især én, mindre engageret og mindre dygtig studerendes udnyttelse af de andre, mere engagerede studerendes initiativer.

På trods af ovenstående udfordringer fremstod de studerendes skriftlige og mundtlige evalueringer efter kursets afvikling langt hen ad vejen positive. Flere af tilbagemeldingerne gik på, at det var "spændende" at komme ud og afprøve kompetencer i virkeligheden, at de studerende fik "mange positive tilbagemeldinger" (fra borgerne) på deres aktiviteter, og at der var mange "gode samtaler" med borgerne. Fordi de studerende stod i foyeren på Kolding Bibliotek, blev de automatisk associeret med bibliotekets øvrige professionelle, hvilket gjorde, at de lejlighedsvis måtte forholde sig til spørgsmål, der rakte ud over deres egne delarrangementer. En enkelt studerende fortalte efterfølgende, hvor fantastisk hurtig tiden under arrangementet var gået, og hvor oplevelsesrigt, det havde været - og hvor træt vedkommende følte sig bagefter. Den konstante agtpågivenhed i interaktion med borgere, hvor hver situation er ny, og hvor de studerende må være parate til at bevæge sig ud over rammerne for deres egentlige opgaver, er uvant og derfor fysisk og mentalt udmattende for den, der ikke er i træning. 


\section{Diskussion}

Hvordan faciliteres en proces, hvor der forsøges skabt rum og adgang for de studerende, så de kan rekontekstualisere deres individuelle erfaringsdannelse og læring? I arbejdet med at realisere en undervisningsplan ud fra Wengers perspektiver, skifter pædagogiske processer og aktiviteter karakter. Én forandring er, at underviser fralægger sig en del af kontrollen med de studerendes asynkrone studieaktiviteter og for eksempel ikke systematisk efterprøver, hvorvidt de studerende faktisk gennemfører deres litteraturstudier, hvordan de når frem til og foretager deres tematiske valg eller hvordan, de vælger at planlægge og organisere deres aktiviteter. I stedet gennemføres fælles evalueringer af de studerendes processer på baggrund af fremlæggelser af delaspekter (brainstorm, tematik, indhold mv.) i plenum. Derved afstår underviser fra nogle af de kontrolmekanismer, som anvendes i klassisk konfrontationsundervisning. I stedet for agerer underviser som facilitator for et fælles fokus hos de studerende, der er rettet imod den opgaveløsning og det produkt, der skal komme ud af de fælles anstrengelser. Det bliver, med andre ord, i højere grad overladt til de studerende at vurdere, hvad der skal til, for at de kan udfylde deres rolle i den praktiske afvikling af situationspraktikken.

At gå fra undervisning til facilitering betyder forandringer af magtbalancer mellem underviser og studerende - og de studerende imellem. For underviser betød overgangen, at forestillingen om, hvem der er aktiv (underviser), og hvem der er passiv (studerende), revideredes. For de studerende betød situationspraktikken, at der var et slutprodukt, der skulle præsenteres i en professionel institutions regi (Kolding Bibliotek), over for et live publikum (borgerne) og i en uvant arkitektonisk ramme (Kolding Biblioteks åbne foyer, hvor alle var synlige hele tiden). Ænndringen betød et større manøvrerum for de studerende at agere i, især for de studerende, der havde kvalifikationerne, ambitionerne og modet til at sætte en normativ standard for situationspraktikken. Praksisfællesskabet på holdet fik herved ny og anderledes næring. Rent illustrativt viste det sig ved, at de to tilvalgsstuderende, som indledningsvist havde haft en perifer plads - både socialt og fysisk i klasseværelset - i løbet af situationspraktikken havde lejlighed til at vise deres niveau af engagement, ambition og initiativ - hvilket fuldt ud matchede de bedste studerende på stamholdet.

Erfaringer med og evalueringer af forløbet viser, at de praktiske erfaringer med arrangementsvirksomhed og publikumsbetjening har nuanceret de studerendes ellers teoretiske, metodiske og analytiske læring. Om situationspraktikken har udfordret de studerendes situerede læring til fulde er dog til diskussion; kan relationer mellem mennesker, der har en tidmæssig udstrækning fra få minutter til et kvarters varighed inden for en 3-timers ramme, skabe et praksisfællesskab? Ikke desto mindre opdagede de studerende, hvordan (noget af) det, de havde erfaret i forskellige fag, kunne anvendes i praksis - og de erfarede, at noget af det, der er behov for i praksis, ikke kan erfares teoretisk-metodisk-analytisk men i stedet må erkendes gennem learning 
by doing. Som sådan spiller situationspraktikken en lille, men vigtig rolle i de nødvendige tilpasninger af de studerendes forforståelser af arbejdet i praksis. Dén erfaring kan ikke opnås gennem nok så meget konfrontationsundervisning. I forlængelse heraf skal det bemærkes, at 9 ud af de 10 studerende fra stamholdet, på et efterfølgende 5 . semester valgte at afvikle 5 eller 10 ECTS-point i ordinære, men stadigt frivillige praktikforløb. Situationspraktikken ser med andre ord ikke ud til at have afskrækket dem fra praksis - tværtimod: én studerende angav direkte erfaringerne fra situationspraktikken som anledning til at vedkommende valgte et ordinært praktikforløb, en mulighed vedkommende egentlig havde afskrevet!

\section{Konklusion}

Forsøget med situationspraktik viser, at selv en rudimentær inddragelse af praksis i undervisningen har potentiale til at synliggøre forskellige fagelementers relevans, så de studerende får en bedre forståelse af, hvad praksis indebærer. Som ved andre former for simulering reducerer situationspraktikken en lang række valg- og handlemuligheder ved, at underviser allerede har truffet en række valg. Herved frigøres de studerende fra hele det problemkompleks, en færdiguddannet skal kunne håndtere og kan i stedet fokusere på den aktuelle opgaveløsning i den konkrete situation og reflekterer over de erfaringer, dette medfører i mødet med praksis. Denne mulighed for at skabe rum for de studerende til at fokusere på problemløsning inden for et afgrænset område af praksis, samt mulighederne for erfaringsdannelse og refleksion, betragter vi som et af kerneelementerne i underviser-som-facilitatorfunktionen.

Som sådan kan situationspraktikken, som den i nærværende artikel omtalte, derfor ikke stå alene: at sende de studerende ud og etablere en 3-timers situationspraktik kan på ingen måder udgøre et fyldestgørende alternativ til besøgspraktikkers intensive all-round introduktion ligeså lidt, som situationspraktik kan stå i stedet for de ordinære praktikforløb af længerevarende karakter. I ordinære praktikforløb har de studerende helt andre muligheder for at indgå i rollen som perifer deltager i de sociale og faglige relationer med de professionelle, der er en forudsætning for etablering af egentlige praksisfællesskaber. Men situationspraktik kan udgøre et væsentligt supplement eller forstudie til disse andre former for praktik.

\section{Transferværdi til andre fag}

Det særegne pædagogisk-didaktiske perspektiv i uddannelsen til bibliotekar er, at den, ulig mange andre bacheloruddannelser, har en bestemt professionsopfattelse indlejret i sig. Implementering af praksisaspektet tvinger underviser til at reflektere over, hvordan denne professionsopfattelse kan fremmes gennem de forskellige teoretiske fremstillinger samt gennem metodiske og analytiske greb. At have en praksis at skulle forholde sig til medfører derfor antageligvis en større overensstemmelse mellem form, indhold og resultat - især når resultatet endvidere er et arrangement, 
der er tiltænkt offentliggørelse. Denne erfaring kan de studerende selvfølgelig opnå ved at gennemføre et længerevarende praktikforløb, men pointen er her, at situationspraktikken er mulig at implementere i den ordinære undervisning, både hvad angår ressourceforbrug i form af tid, omfang og energi og i forhold til studieordningen. Besøgspraktikkerne kan ikke tilnærmelsesvis skabe samme sammenhængende fokus på et afgrænset område eller rum for afprøvning over for borgere. Og længerevarende praktikforløb kræver dispensation og/eller studieordningsændringer for at kunne indgå i ordinære undervisningsforløb.

Et andet aspekt af praktik som undervisningsform er dens mulighed for at skabe rum for mødet mellem kommende professionel og publikum/borger/kunde/patient/klient m.fl. I mere dynamisk konfrontationsundervisning er det muligt at simulere en lang række færdigheder, viden og kompetencer og herigennem give de studerende muligheder for at gøre sig erfaringer med disse i tænkte situationer. Men samspillet mellem profession og person, hvor færdigheder, viden og kompetencer sekunderes af forskellige grupper eller individers forskellige sociale og kulturelle normer, værdier og traditioner, kan kun verbaliseres - ikke simuleres. Dette samspil kan kun erfares i sin fulde konsekvens ved at opsøge praksis. Som sådan kan situationspraktikken ses som en mulig pendant til for eksempel sundhedsuddannelsernes klinikperioder eller praktisk-teoretiske fags værksteds- eller laboratorieperioder.

Bo Skøtt er ph.d. og adjunkt ved Institut for design og kommunikation på Det humanistiske Fakultet ved SDU i Kolding. Han forsker og underviser i bibliotekskundskab og vidensformidling med scerlig fokus på folkebiblioteker, deres opgavevaretagelse og funktionsudfyldelse i samfundet. Han har tidligere beskaftiget sig med blandt andet målgruppestudier, kulturformidling og informelle loeringsaktiviteter i forbindelse med introduktion af digitale medier på folkebibliotekerne.

Rie Troelsen er leder af SDU Universitetspaedagogik på SDU, hvor hun arbejder med undervisnings- og uddannelsesudvikling og med efteruddannelse og kompetenceudvikling hos universitetsansatte. Forskningsmaessigt har Ries arbejde iscer centreret sig om professionaliseringen af universitetsundervisningen/-underviseren og omkring mødet mellem studerende og studium. Herudover er hun i de senere år begyndt at interessere sig for samspillet mellem loering og det fysiske loeringsrum.

\section{Litteratur}

Det Humanistiske Fakultet SDU (2015). Studieordning for Bibliotekskundskab og Videnskommunikation. Retrieved from http://sdu.dk/Uddannelse/Bachelor/Bibliotekskundskab_og_videnskommunikat ion/Uddannelsens_opbygning/Studieordning 
Knight, P. T. \& Yorke, M. (2004). Learning, Curriculum and Employability in Higher Education. London: RoutledgeFalmer.

Lave, J. \& Wenger, E. (2003). Situeret loering - og andre tekster. København: Hans Reitzels Forlag.

Lindhart, L. (2007). Loering som deltagelse i vekslende handlesammenhoenge. Hvor loerer en loerer at vore loerer? Ph.d.-afhandling, Aalborg Universitet.

Rasmussen, J. (1999). Mesterlære og den almene pædagogik. I K. Nielsen \& S. Kvale (red.): Mesterloere. Laering som social praksis. København: Hans Reitzels forlag, 199-218.

Ulriksen, L., Madsen, L. M. \& Holmegaard, H. T. (2014). The first-year experience: Students' encounter with science and engineering programmes. I E. K. Henriksen, J. Dillon \& J. Ryder (red.): Understanding Student Participation and Choice in Science and Technology Education. Dordrecht: Springer Science+Business Media, 241-257.

Wenger, E. (1998). Communities of Practice: Learning, Meaning, and Identity. Cambridge: Cambridge University Press. 